\title{
Effect of green macroalgal mats on burial depth of soft-shelled clams Mya arenaria
}

\author{
Lise M. Auffrey ${ }^{1, *}$, Shawn M. C. Robinson ${ }^{2}$, Myriam A. Barbeau $^{1}$ \\ ${ }^{1}$ Department of Biology, University of New Brunswick, Bag Service 45111, Fredericton, New Brunswick E3B 6E1, Canada \\ ${ }^{2}$ St. Andrews Biological Station, Department of Fisheries and Oceans, 531 Brandy Cove Road, St. Andrews, \\ New Brunswick E5B 2L9, Canada
}

\begin{abstract}
Green macroalgal mats are becoming prevalent in many parts of the world, including on important clam-harvesting beaches in SW New Brunswick, Canada. Such mats (Enteromorpha sp. and Cladophora sp.) may be affecting populations of soft-shelled clams Mya arenaria (L.). We investigated the effect of these mats on burial depth of soft-shelled clams in the field ( 2 impacted sites with high algal cover and 2 reference sites with no algal mats) and laboratory. At impacted sites, burial depth was significantly shallower for clams under macroalgal mats than for those in areas clear of algae. In the comparison of areas clear of algae at impacted sites to the reference sites, clam burial depth was not significantly different; rather, burial depth varied between sites independent of site type. Field measurements of benthic respiration and total sulfides were significantly higher in areas in which algal mats were present than in areas in which they were absent. In an $8 \mathrm{~d}$ laboratory experiment, clams (4 per aquarium) were placed in sand $(10 \mathrm{~cm}$ deep) and covered with 0,2 or $6 \mathrm{~cm}$ of macroalgae. Clam burial depth quickly decreased under algae and remained significantly shallower under 2 and $6 \mathrm{~cm}$ of algae than in the control (no algae). Near the end of the experiment, we removed the algae, and burial depth quickly increased. At the end of the experiment, clam body mass and dissolved oxygen at the sediment surface did not differ significantly between treatments, although both variables showed a decreasing trend with increasing algal mat cover. Dissolved organic carbon in pore water at the end of the experiment was significantly higher in the $6 \mathrm{~cm}$ algal treatment than in the control and $2 \mathrm{~cm}$ algal aquaria. The presence of algal mats clearly affects burial depth of softshelled clams. This in turn may have impacts on predator-clam interactions and on the surrounding environment.
\end{abstract}

KEY WORDS: Bay of Fundy · Eutrophication $\cdot$ Filamentous green algae $\cdot$ Infauna $\cdot$ Behavior

Resale or republication not permitted without written consent of the publisher

\section{INTRODUCTION}

Coastal eutrophication, the over-enrichment of coastal zones with inorganic and organic nutrients, is becoming a global phenomenon (Rosenberg 1985, Loo \& Rosenberg 1989, Strain \& Yeats 1999, Cloern 2001). Increases in anthropogenic activities near coastal zones (e.g. housing developments, aquaculture, agriculture) and atmospheric deposition augment nutrient levels, such as nitrogen and phosphorus, in coastal waters. The impact of this enrichment depends on the capacity at which the environment can receive and absorb these excess nutrients (Strain \& Yeats 1999,
Cloern 2001). A common feature of additional nutrient loading in many locations is an increase in the formation of dense green macroalgal mats composed mainly of Enteromorpha sp. and Ulva sp. (Reise et al. 1989, Lavery \& McComb 1991, Kolbe et al. 1995, Auffrey 2003).

Green macroalgal mats have been documented to decrease invertebrate abundance, diversity and growth (Nicholls et al. 1981, Soulsby et al. 1982, Everett 1994, Norkko \& Bonsdorff 1996a,b,c, Thiel et al. 1998), and affect behavior by causing vertical migration in benthic infauna (Norkko \& Bonsdorff 1996a,b,c, Norkko et al. 2000, Österling \& Pihl 2001). 
Impacts on bivalves have been attributed to changes in sediment chemistry, water chemistry at the sediment-water interface (e.g. hypoxia), and the physical environment (e.g. decreased water flow) caused by dense macroalgal mats (Nicholls et al. 1981, Hull 1987, Bonsdorff 1992, Isaksson \& Pihl 1992, Everett 1994, Escartin \& Aubrey 1995, Norkko \& Bonsdorff 1996a,b,c, Norkko et al. 2000). Hypoxic conditions, presumably created by dense algal mats, result in organisms altering their behavior (e.g. migration), physiological condition (e.g. increased respiration), feeding abilities, and reproductive output (Diaz \& Rosenberg 1995 and references therein).

Soft-shelled clams Mya arenaria (L.) are bivalves distributed along the western North Atlantic coast from Labrador to South Carolina, the European coast, and the Pacific coast from Alaska to California (Strasser 1999). They inhabit muddy to gravel substrates from the intertidal zone down to $200 \mathrm{~m}$ in depth, but are most abundant in intertidal and shallow subtidal areas (Strasser 1999). Following a planktotrophic larval development stage, they settle on the bottom, burrow in the sediment and permanently inhabit that area unless conditions deteriorate or the clams are washed away. As a soft-shelled clam matures, its siphon elon- gates allowing the animal to burrow deeper into the sediment (Zwarts \& Wanink 1989). Hypoxic conditions at the water-sediment interface have been shown to affect the behavior of soft-shelled clams both in the field and laboratory (Jørgensen 1980, Rosenberg et al. 1991, Taylor \& Eggleston 2000). Therefore, the presence of algal mats on mudflats where clams occur, and their associated changes to environmental conditions, may also be affecting behavior.

The present study investigated clam behavior, specifically burial depth, in the presence and absence of green macroalgal mats in the field and laboratory. We predicted that clam burial depth would be shallower in the presence of green macroalgal mats than in their absence because of the altered environmental conditions caused by these mats (Nicholls et al. 1981, Hull 1987, Bonsdorff 1992, Isaksson \& Pihl 1992, Everett 1994, Escartin \& Aubrey 1995, Norkko \& Bonsdorff 1996a,b,c, Norkko et al. 2000). We measured clam burial depth in field sites with high algal mat cover, both in areas covered with and free of algal mats. We also measured burial depth in field sites with no algal mat cover. Finally, we performed a laboratory experiment on the effect of different algal mat thicknesses on clam burial depth, clam body mass and abiotic variables.

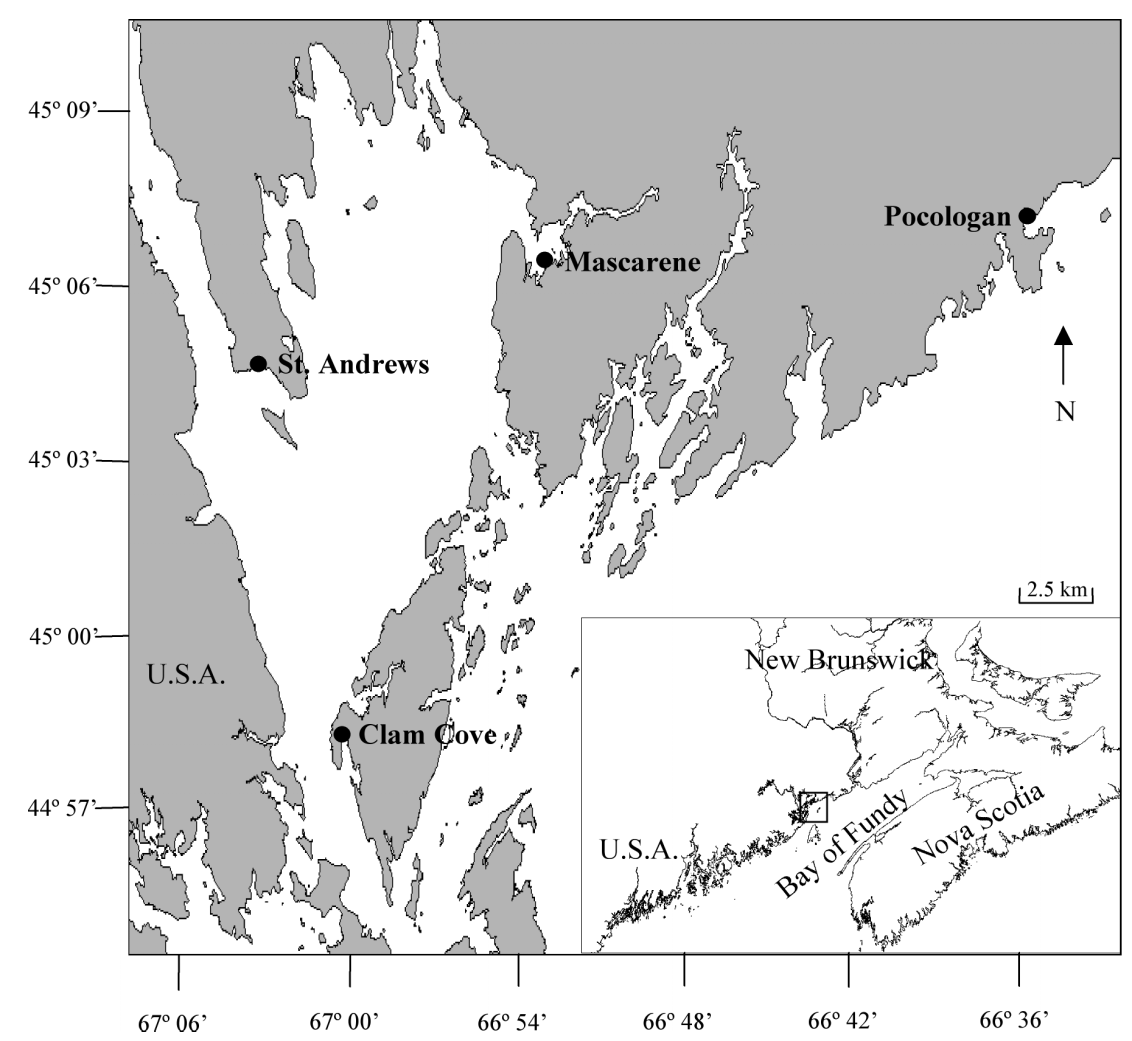

Fig. 1. The study area in SW New Brunswick, Canada, showing our 4 sites ( 2 impacted sites and 2 reference sites)

\section{MATERIALS AND METHODS}

Field sampling. Burial depth of softshelled clams Mya arenaria (L.) was measured at 4 sites in SW New Brunswick (Fig. 1) on 24 to 26 June and 2 to 7 August 2001. The sites included 2 impacted mudflats with high green macroalgal cover (up to $40 \%$ cover of mostly Enteromorpha sp. and <5\% Cladophora sp., Auffrey 2003), St. Andrews Blockhouse and Clam Cove on Deer Island, and 2 reference mudflats with no macroalgal cover, Pocologan and Mascarene. At the impacted sites, clam burial depth was measured in areas covered with macroalgal mats and in clear areas.

To measure clam burial depth, 2 to 4 trenches (30 cm deep) were dug in haphazardly chosen locations at the impacted sites (in both areas covered and free of mats) and at the reference sites. The walls of the trenches were gently scraped away with a trowel and, upon reaching a clam, burial depth was recorded by measuring the distance between the posterior edge of the clam 
and sediment surface with a plastic ruler to the nearest $\mathrm{mm}$. For a given month and area, 30 to 60 clams were sampled.

Sediment cores for total oxygen uptake (respiration) measurements were collected on 18 and 19 July 2001 in Mascarene $(n=6)$ and Clam Cove $(n=4$ for each of the areas with and without algal mats), respectively. Sample collection and laboratory analysis were as described in Hargrave et al. (1983). Concurrently, $5 \mathrm{ml}$ cores were collected from the upper $2 \mathrm{~cm}$ of the intertidal sediment using cut-off $5 \mathrm{ml}$ syringes for measurements of total sulfides ( $\mathrm{n}=6$ for each of Mascarene and Clam Cove in an area with and an area without algal mats). These samples were capped, labeled with common identifier labels, and stored on ice for up to $24 \mathrm{~h}$ until analysis. The syringe was then ejected into a $100 \mathrm{ml}$ biotight jar and the sediment was diluted with $5 \mathrm{ml}$ of sulfide anti-oxidant buffer solution (SAOB). Measurements of sulfide $\left(\mathrm{S}^{2-}\right)$ were obtained as described in Hargrave et al. (1995).

Laboratory experiment. The effect of different algal thicknesses on burial depth of soft-shelled clams was investigated in a laboratory experiment performed between 31 July and 8 August 2001 at the St. Andrews Biological Station. Aquaria (10 1, $14.3 \mathrm{~cm}$ [width] $\times 29.5 \mathrm{~cm}$ [height] $\times 23.8 \mathrm{~cm}$ [length]), each containing 4 large juvenile clams $(2.9 \pm 0.8 \mathrm{~g}$ fresh mass, $26.8 \pm$ $2.5 \mathrm{~cm}$ shell length, $16.9 \pm 1.7 \mathrm{~cm}$ shell height [mean \pm $\mathrm{SD}$ ]) buried in $10 \mathrm{~cm}$ of sand, had 1 of 3 algal thicknesses (mostly Enteromorpha sp. and $<5 \%$ Cladophora sp.) placed on the sediment: $0 \mathrm{~cm}$ (control), $2 \mathrm{~cm}$ $(215.9 \pm 0.2 \mathrm{~g}$ wet mass [mean $\pm \mathrm{SD}])$ or $6 \mathrm{~cm}(645.6 \pm$ $0.4 \mathrm{~g}$ wet mass). There were 3 replicate aquaria per algal treatment (total of 9 aquaria). Burial depth of each clam was measured daily. Clam survival was checked at the end of the experiment. Dissolved organic carbon in the sediment and dissolved oxygen at the sediment-algal (or sediment-water) interface were measured at the beginning and end of the experiment.

Clams were collected at the Blockhouse, St. Andrews, on 24 July 2001 and maintained in fresh continuously flowing seawater until transplanted in experimental aquaria. Green macroalgae were collected at the Blockhouse on 30 July 2001, rinsed in seawater to remove small invertebrates and placed in a tank with running seawater until the start of the experiment. Sand was collected at the Blockhouse, sieved with a $2 \mathrm{~mm}$ mesh in freshwater to remove large-sized particles and placed in the experimental aquaria $(10 \mathrm{~cm}$ deep). Fresh seawater flowed over the sediment in the aquaria for $24 \mathrm{~h}$ before the addition of clams.

Semi-diurnal tides were simulated in the aquaria during the experiment. The aquaria were set up as follows (Fig. 2). Two $0.4 \mathrm{~cm}$ holes were drilled on 1 side of each aquarium, $10.5 \mathrm{~cm}$ from the bottom; one hole was open to allow outflow of seawater at the sediment surface and the other hole was plugged with silicone (and used to sample dissolved oxygen with a syringe, see below). Three $0.4 \mathrm{~cm}$ overflow holes were drilled on another side of each aquarium, $1.2 \mathrm{~cm}$ from the top. A solenoid valve, connected to the main seawater pipe, was plugged into an electric timer to control the opening and closing of the valve. Seawater flowed into each aquarium for $6 \mathrm{~h}$, starting at 09:00 and 21:00 h (and was off at 15:00 and 03:00 h). Upon closing of the valve, the seawater would empty out. The inflow was set at 72.0 to $75.6 \mathrm{l} \mathrm{h}^{-1}$, and outflow at the sediment surface was $72.4 \pm 5.2 \mathrm{l} \mathrm{h}^{-1}$ (mean $\left.\pm \mathrm{SD}\right)$ at the simulated high tide. The inflow was aimed at the back wall of each aquarium to create a gentle flow of water during high tides and avoid direct flow onto the sediment or algal layer. The outflow holes were cleaned every day with a dissecting needle to allow proper flow.

Salinity and temperature of the water were measured each day and were consistent throughout the experiment (temperature $=13.3 \pm 0.4^{\circ} \mathrm{C}[$ mean $\pm \mathrm{SD}]$; salinity $=31.4 \pm 0.30 \%$ ). A growth light (Sylvania Gro-lux F40/GRO/AQ/RP) was placed over the experimental aquaria and daily photoperiod was set at $14 \mathrm{~h}$ light:10 h dark (on at 07:00 h, off at 21:00 h) to simulate natural lighting conditions at the time of the experiment.

To monitor individual clams during the experiment, we affixed on the shell of each a plastic numbered tag $(4 \times 10 \mathrm{~mm})$ and a $40 \mathrm{~cm}$ long monofilament line (nylon line, $20 \mathrm{~kg}$ ) using cyanoacrylate glue, $1 \mathrm{~d}$ prior to planting in experimental aquaria. After gluing, the

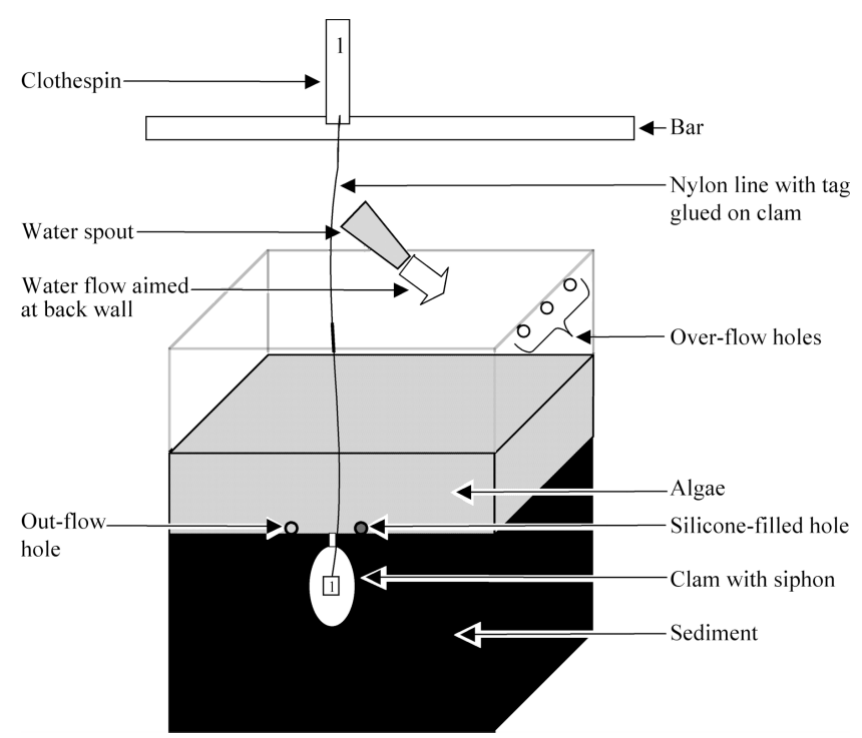

Fig. 2. An experimental aquarium. Dimensions of aquarium are $14.3 \mathrm{~cm}$ (width) $\times 29.5 \mathrm{~cm}$ (height) $\times 23.8 \mathrm{~cm}$ (length). Sediment $(10 \mathrm{~cm})$ was placed in the aquarium and was covered with either 0,2 or $6 \mathrm{~cm}$ of algae 
length of the line was cut so that the length between the posterior end of the clam and tip of the line measured $35 \mathrm{~cm}$. After placing the clams in the experimental aquaria, the line was secured (leaving some slack in the line) with a numbered clothespin, matching the clam number, to a bar above the aquarium (Fig. 2). The clams, randomly assigned to the experimental treatments, were allowed to acclimate and burrow for $24 \mathrm{~h}$ prior to the addition of algae. Clam shell length did not vary between treatment levels $\left(F_{2,29}=1.07, p=0.36\right)$. During the experiment, burial depth was measured at the simulated low tide by unfastening the clothespin and gently placing the line against a long, thin wooden dowel, vertically placed on the sediment surface, adjacent to the clam being examined. The top of the line was marked on the vertical dowel with a lead pencil. We then measured the distance between the bottom of the dowel and the mark, and subtracted this value from $35 \mathrm{~cm}$ to obtain burial depth for a particular clam.

Dissolved organic carbon (DOC) was measured at the beginning of the experiment (prior to addition of algae) in 3 randomly (using a random number table) chosen aquaria, and at the end of the experiment in all 9 aquaria. Nalgene bottles $(50 \mathrm{ml})$ were filled halfway with sediment and topped off with seawater from the aquaria. The bottles were lightly shaken and placed overnight in a refrigerator to allow particle settlement. The cooled supernatant was drawn in a sterile syringe and filtered through a pre-ashed GF/F filter (at the St. Andrews Biological Station) into a clean bottle and frozen until analyzed (at the Bedford Institute of Oceanography), as described in Bugden et al. (2001).

Dissolved oxygen was measured at the beginning of the experiment (prior to addition of algae) in 3 randomly chosen aquaria and at the end of the experiment in all 9 aquaria, both at night (when algae are respiring only) and during the day (when algae are photosynthesizing and respiring). We extracted $180 \mathrm{ml}$ of water at the sediment interface with a $60 \mathrm{ml}$ syringe and 16gauge needle (38 mm long) through the silicone-filled hole. The water was gently poured from the syringe into a conical flask by removing the needle and applying slow and steady pressure to the plunger. Contact with atmospheric oxygen and stirring or shaking of the flask were kept to a minimum. Winkler analysis for dissolved oxygen was done as described in Levy et al. (1977).

One day before the end of the experiment, the algae were removed and re-weighed to check for differences between initial and final algal cover (final $2 \mathrm{~cm}=190.6$ $\pm 7.5,6 \mathrm{~cm}=630.8 \pm 67.9 \mathrm{~g}$ wet mass [mean $\pm \mathrm{SD}]$ ). Clams were left in the experimental aquaria for an additional $24 \mathrm{~h}$ to see if their burial depth would change after the algae had been removed. After com- pletion of the experiment, body mass analyses were performed on the experimental clams.

To assess body mass, the clams were first placed in seawater for $24 \mathrm{~h}$ in order to allow depuration of the gut (Hawkins \& Rowell 1987). Prior to dissecting, wet fresh mass (g), shell length $(\mathrm{mm})$, and shell height $(\mathrm{mm})$ were measured. The clams were then dissected with a spatula, and the tissues were blot-dried to remove excess water. The tissues were dried in a $60^{\circ} \mathrm{C}$ drying oven for $48 \mathrm{~h}$ and then re-weighed.

Effect of nylon line. Concurrent with the above laboratory experiment, a small laboratory experiment was conducted to assess the effect of the nylon line on clam burial depth. Each of 3 algal treatments $(0,2$ and $6 \mathrm{~cm}$ algal thickness) was set up in an aquarium (total of 3 aquaria). Four clams were deployed per aquarium: 2 with nylon line and 2 without nylon line. Other experimental conditions (tidal cycle, temperature, salinity and lighting) were as in the above experiment. For clams affixed with a nylon line, burial depth was measured on a daily basis; for clams without a nylon line, burial depth was observed only at the end of the experiment.

Statistical analysis. Measurements of clam burial depth from the impacted sites (Clam Cove and St. Andrews) were analyzed for each site separately, using 2-way ANCOVA (analysis of covariance) with time (2 levels: June, August) and algal presence (2 levels: presence and absence of algal mat) as fixed factors, and clam shell length as the covariate. We could not use a 3-way ANCOVA with site, time and algal presence as factors because the assumption of homogeneity of regression slopes was not met. Assumption of normality was examined visually by inspection of the residuals. Homogeneity of variance and homogeneity of regression slopes were checked as described in Huitema (1980). To meet the assumptions of normality and homogeneity of variance, a reflexion transformation (Tabachnick \& Fidell 1983) was applied to data from Clam Cove and a square-root transformation was applied to data from St. Andrews. Post hoc comparisons for the detection of a significant interaction were done using a simple effects test (Huitema 1980).

To compare field burial depths from the areas without algae at the impacted sites to those from the reference sites (Pocologan and Mascarene), we ran a nested ANCOVA with type of site (2 levels: reference, impacted-algae absent) and time (2 levels: June, August) as fixed factors, and site as a random factor nested within type. Clam shell length was the covariate. Assumptions of normality, homogeneity of variance, and homogeneity of regression slopes were checked as described above, and were met.

We analyzed measurements of respiration and total sulfides from the field as follows: (1) measurements 
Table 1. Mya arenaria. ANCOVA examining the effects of algal mats (presence, absence) and month (June, August) on burial depth for each of the 2 impacted sites. Prior to analysis, a reflexion transformation $(\sqrt{ } K-X$, where $K$ represents the maximum value of $X+1$, and $X$ the data) was applied to data from Clam Cove; a square-root transformation was applied to data from St. Andrews. For post hoc comparisons, treatment levels are listed in increasing magnitude of their mean; those sharing a common underline do not differ significantly, as determined by simple effects test. $\mathrm{A}=$ algal presence, NA = algal absence, Aug = August

\begin{tabular}{|c|c|c|c|c|c|c|}
\hline Site & Source of variation & df & MS & $F$ & $\mathrm{p}$ & Post hoc comparison \\
\hline \multirow[t]{5}{*}{ Clam Cove } & Month & 1 & 14.29 & 15.13 & $<0.001$ & \\
\hline & Algae & 1 & 85.33 & 90.30 & $<0.001$ & \\
\hline & Month $\times$ Algae & 1 & 1.81 & 1.91 & 0.17 & \\
\hline & Clam length & 1 & 105.43 & 111.57 & $<0.001$ & \\
\hline & Error & 115 & 0.95 & & & \\
\hline \multirow[t]{8}{*}{ St. Andrews } & Month & 1 & 0.34 & 0.55 & 0.46 & \\
\hline & Algae & 1 & 35.43 & 57.70 & $<0.001$ & \\
\hline & Month $\times$ Algae & 1 & 2.75 & 4.48 & 0.037 & A: Aug June \\
\hline & & & & & & NA: June Aug \\
\hline & & & & & & June: A NA \\
\hline & & & & & & Aug: A NA \\
\hline & Clam length & 1 & 66.16 & 107.74 & $<0.001$ & \\
\hline & Error & 115 & 0.61 & & & \\
\hline
\end{tabular}

from areas with and without algal mats in Clam Cove were compared using a paired $t$-test, and (2) measurements from Mascarene and the area without algal mats in Clam Cove were compared using 2-sample $t$-tests (Zar 1999). The data for respiration met all assumptions, while the data for total sulfides were transformed using natural logarithm.

Clam burial depths observed in the laboratory experiment were analyzed using a nested, repeatedmeasures ANOVA with algal thickness (3 levels: 0, 2, $6 \mathrm{~cm}$ ) as a fixed factor, aquarium (3 levels) as a nested random factor, and time (Days 1 to 7 ) as a repeated factor. Data from 1 aquarium in the $2 \mathrm{~cm}$ algal treatment were not used because the algal mat did not settle on the sediment during simulated high tide as in the other experimental aquaria (it floated). In addition, 2 clams died in the $6 \mathrm{~cm}$ algal treatment on Day 5; we included burial depths of these clams in our analysis for Days 1 to 4 only (during those $4 \mathrm{~d}$ their behavior was very similar to their conspecifics). The data met the assumptions of sphericity (Potvin et al. 1990), normality (inspected visually) and homogeneity of variance (verified using Cochran's C-test). Post hoc comparisons were performed using the Student-NewmanKeuls (SNK) test (Winer 1971).

Other measurements obtained at the beginning and at the end of the laboratory experiment were analyzed as follows. Initial oxygen and DOC measurements were compared to final measurements in the control aquaria with 2 -sample $t$-tests (Zar 1999). Final clam burial depth (Day 8), clam body mass and DOC were all analyzed using a 1-way ANOVA with algal thickness as a fixed factor. The 2 dead clams in the $6 \mathrm{~cm}$ algal treatment were not included in the analysis of body mass. Dissolved oxygen was analyzed using a repeated-measures ANOVA with algal thickness as a fixed factor and time (2 levels: day, night) as the repeated factor. Assumptions of normality and homogeneity of variance were tested as indicated above and were met, except for oxygen measurements in the comparison between the beginning and the end of the experiment (these were transformed using natural logarithm).

\section{RESULTS}

\section{Field sampling}

At both impacted sites, clam burial depth was significantly shallower in the presence of algae than in their absence (Table 1, Fig. 3). We actually observed a few clams that were on the sediment surface under algae in June in Clam Cove. Clam burial depth was shallower here in June than in August. In St. Andrews, burial depth showed no significant difference between the 2 mo.

Comparison of the areas clear of algal mats in the impacted sites to the reference sites showed that clam burial depth was not significantly affected by mudflat type (Table 2, Figs. 3 \& 4). Rather, it varied between sites independently of mudflat type. Clam burial depth tended to be shallower in June than in August, but this trend was non-significant.

Although we did not measure oxygen concentrations at the sediment-algal interface in the field, black, sulfurous-smelling surface sediments under macroalgal mats indicated hypoxic conditions. Comparison of total oxygen uptake under algal mats and in areas clear of algae in Clam Cove indicated that respiration 


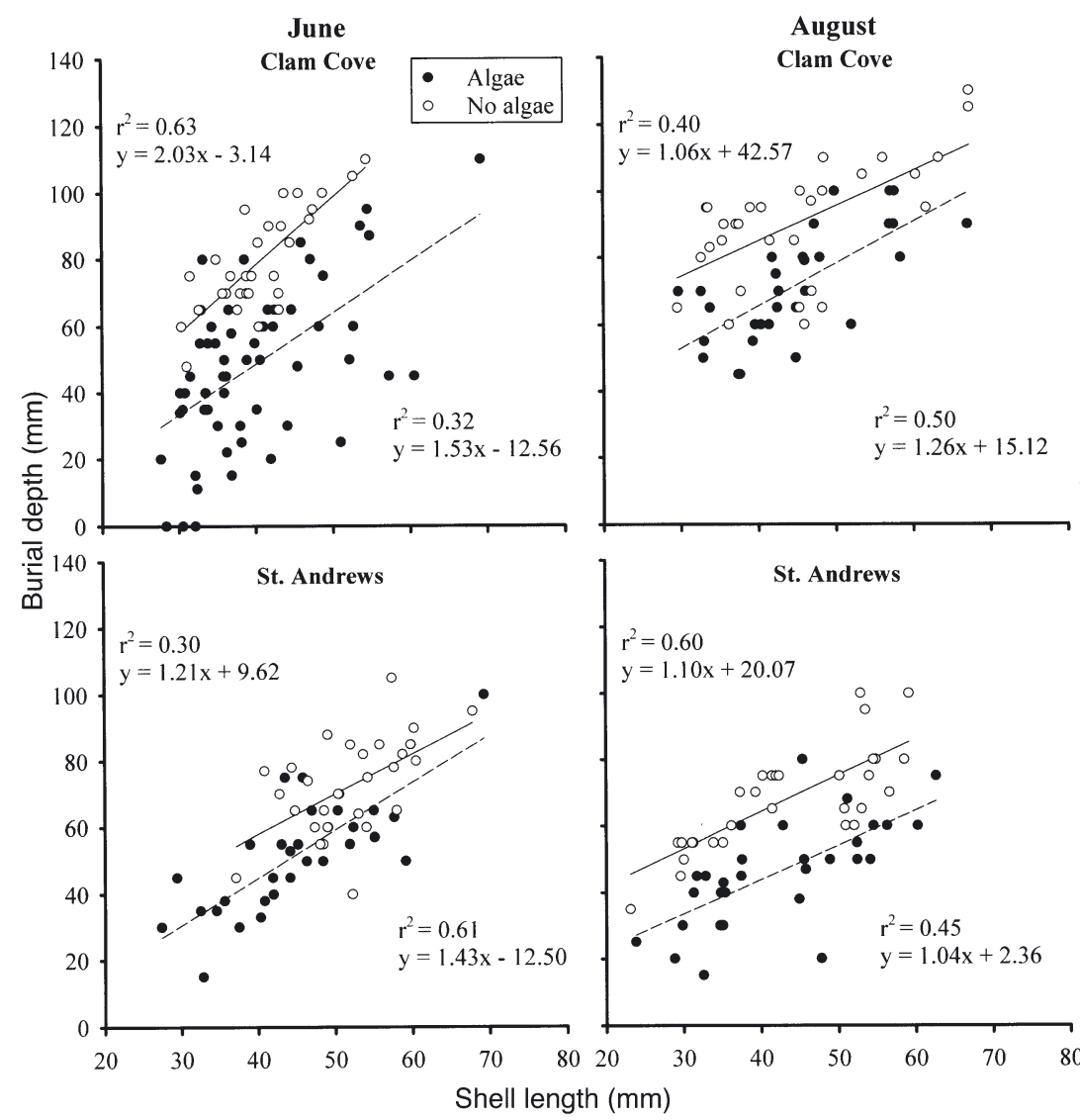

Fig. 3. Mya arenaria. Relationship between burial depth and shell length at impacted sites in the presence and absence of algal mats

in covered areas was higher than in algae-free areas (Fig. $5, t_{3}=4.12, \mathrm{p}=0.026$ ). Total oxygen uptake in areas clear of algae in Clam Cove was significantly lower than that in the reference site (Mascarene) $\left(t_{8}=\right.$ 2.72, $\mathrm{p}=0.026)$.
In Clam Cove, measurements of total sulfides under algal mats were significantly higher than those in areas clear of algae (Fig. 5, $t_{5}=4.43, \mathrm{p}=0.007$ ). Total sulfides in areas clear of algae in Clam Cove were significantly higher than in Mascarene $\left(t_{10}=3.23, \mathrm{p}=0.009\right)$.

\section{Laboratory experiment}

The nylon line did not prevent the burrowing abilities of clams. In our small experiment that examined the effect of the nylon line, tethered and non-tethered clams migrated vertically in the 2 and $6 \mathrm{~cm}$ algal treatments, but remained burrowed in the control aquaria.

One day after the addition of algae to aquaria in our main experiment, clam burial depth decreased dramatically (Fig. 6). For most of the remainder of the experiment (Days 1 to 7), burial depth remained significantly shallower in the aquaria with algae than in the control aquaria (Table 3, Fig. 6). Although clams tended to be buried shallower in the $6 \mathrm{~cm}$ algal treatment level than in the $2 \mathrm{~cm}$ algal treatment level, this trend was not significant. On Day 7, 7 out of 8 clams and 10 out of 12 clams were on the sediment surface in the $2 \mathrm{~cm}$ algal treatment level and $6 \mathrm{~cm}$ algal treatment level, respectively (Fig. 6). Once all algae were removed (Day 8), clams quickly increased their burial depth (Fig. 6), with no significant difference in burial depth between treatments $\left(F_{2,23}=1.869, \mathrm{p}=0.18\right)$.

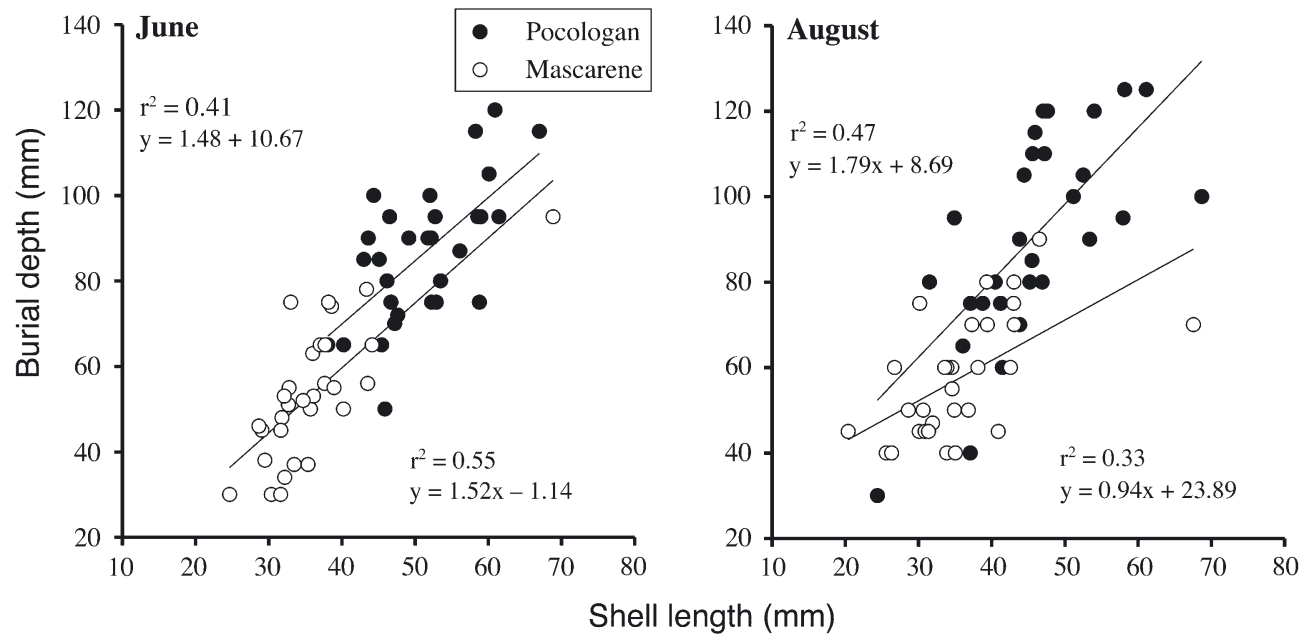

Fig. 4. Mya arenaria. Relationship between burial depth and shell length at reference sites (algal mats absent) 

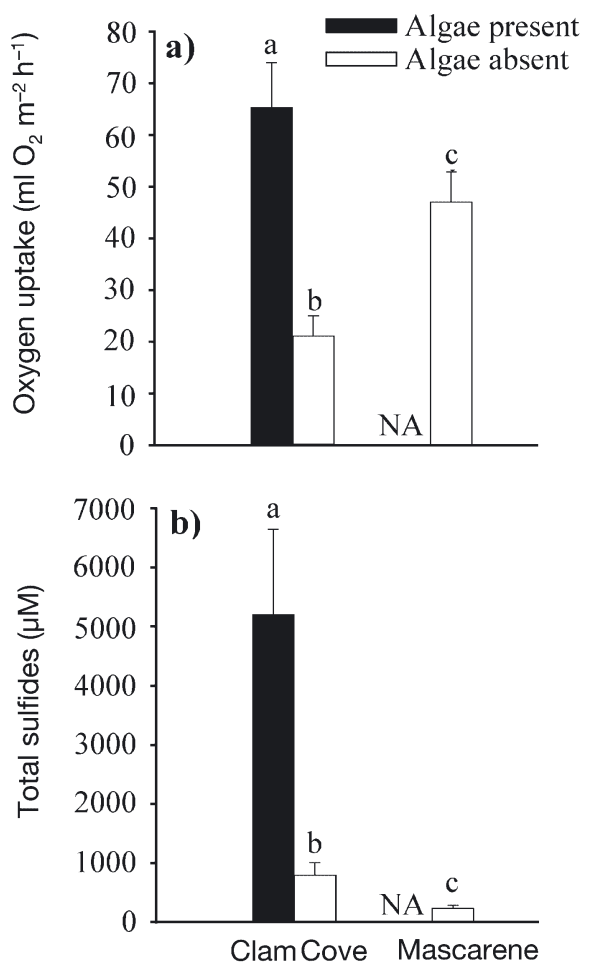

Fig. 5. (a) Mean benthic oxygen uptake and (b) total sulfides in Clam Cove (impacted site with areas covered with and clear of algal mats) and Mascarene (reference site). Error bar = $1 \mathrm{SE}$;

$\mathrm{n}=4$ to 6 . Bars with different letters differ significantly

Although clam dry body mass tended to decrease with increasing algal thickness (Fig. 7a), the trend was not significant $\left(F_{2,27}=1.828, \mathrm{p}=0.18\right)$.

Initial and final dissolved oxygen concentrations in the control aquaria did not differ significantly $\left(t_{4}=1.40\right.$, $p=0.24)$. At the end of the experiment, dissolved oxygen tended to be lower in the $6 \mathrm{~cm}$ algal treatment than in the other algal treatment levels (Fig. 7b). In the

Table 2. Mya arenaria. Nested ANCOVA examining the effect of mudflat type (impacted, reference) and month (June, August) on burial depth. Site is a random factor, nested in mudflat type (Clam Cove and St. Andrews for the impacted sites, and Pocologan and Mascarene for the reference sites). Note that for the impacted sites, we used data for areas clear of algal mats in this analysis

\begin{tabular}{|lcrrc|}
\hline Source of Variation & df & MS & $F$ & $\mathrm{p}$ \\
\hline Month & 1 & 2764.07 & 15.23 & 0.060 \\
Type & 1 & 112.35 & 0.011 & 0.93 \\
Site(Type) & 2 & 10360.64 & 63.73 & $<0.001$ \\
Month $\times$ Type & 1 & 54.49 & 0.30 & 0.64 \\
Month $\times$ Site(Type) & 2 & 181.43 & 1.12 & 0.33 \\
Clam length & 1 & 28863.70 & 177.55 & $<0.001$ \\
Error & 230 & 162.57 & & \\
& & & & \\
\hline
\end{tabular}

presence of algae, dissolved oxygen also tended to be higher at night than in the day (Fig. 7b). However, none of these trends was significant (Algae: $F_{2,5}=4.10$, $\mathrm{p}=0.088$; Time: $F_{1,5}=0.11, \mathrm{p}=0.76$ ) because, we suspect, of a sampling artifact (as discussed in the 'Discussion' section). At the end of the experiment we observed black, sulfurous-smelling sediments in the 2 and $6 \mathrm{~cm}$ algal treatment levels, and brown, nonsmelly sediments in the control aquaria.

Initial DOC did not differ significantly from final DOC in the control aquaria (Fig. $7 \mathrm{C}, t_{4}=2.70, \mathrm{p}=$ 0.054). At the end of the experiment, DOC was significantly higher in the $6 \mathrm{~cm}$ algal treatment level than in the $2 \mathrm{~cm}$ algal treatment level and control aquaria $\left(F_{2,5}=10.92, \mathrm{p}=0.015\right)$.

\section{DISCUSSION}

As predicted, the burial depth of soft-shelled clams Mya arenaria was shallower in the presence of green macroalgal mats than in the absence, both in the field and laboratory. We also observed clams at the sediment surface under algal mats at 1 impacted site (Clam Cove) and in our laboratory experiment. Vertical migration to the sediment surface under macroalgal mats has been observed for bivalves such as Cerastoderma spp. and Macoma balthica in the laboratory and field (Norkko \& Bonsdorff 1996a,b,c, Norkko et al. 2000, Österling \& Pihl 2001), and for Mya sp. in an intertidal mudflat (Thiel et al. 1998). Vertical migration of bivalves into the overlying algal mats has also been documented

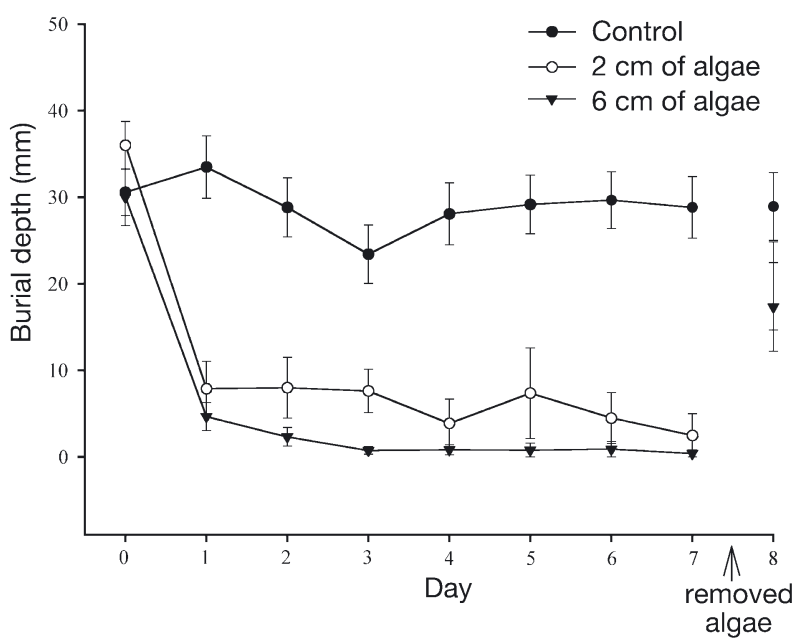

Fig. 6. Mya arenaria. Burial depth (mean \pm SE) during an $8 \mathrm{~d}$ laboratory experiment which examined the effect of algal thickness (either 0, 2 or $6 \mathrm{~cm}$ ). See Fig. 2 for aquarium set-up. Algae were removed from $2 \mathrm{~cm}$ and $6 \mathrm{~cm}$ algal treatment levels on Day 7 and final burial depth in all aquaria was taken on Day 8. $\mathrm{n}=6$ to 12 
Table 3. Mya arenaria. Repeated-measures ANOVA examining the effect of algal thickness $(0,2,6 \mathrm{~cm})$ on burial depth during an $8 \mathrm{~d}$ laboratory experiment. For the post hoc comparisons (SNK), treatment levels are listed in increasing magnitude of their mean; those sharing a common underline do not differ significantly

\begin{tabular}{|c|c|c|c|c|c|}
\hline Source of variation & df & MS & $F$ & $\mathrm{p}$ & Post hoc comparison \\
\hline $\operatorname{Algae}^{\mathrm{a}}$ & 2 & 15697.39 & 31.80 & $<0.001$ & $\underline{62} 0$ \\
\hline Aquarium(Algae) & 6 & 493.72 & 1.09 & 0.40 & \\
\hline Error $_{\text {between }}$ & 21 & 453.99 & & & \\
\hline Time $^{\mathrm{b}}$ & 6 & 75.60 & 1.79 & 0.13 & \\
\hline Time $\times$ Algae $^{b}$ & 12 & 24.16 & 0.57 & 0.85 & \\
\hline Time $\times$ Aquarium(Algae) & 36 & 42.28 & & & \\
\hline Error $_{\text {within }}$ & 126 & 16.73 & & & \\
\hline \multicolumn{6}{|c|}{$\begin{array}{l}\text { a Aquarium(Algae) is a random factor. The denominator for the F-ratio of } \\
\text { Algae is Aquarium(Algae) } \\
\text { b } \text { The denominator for the F-ratio of these factors is Time } \times \text { Aquarium(Algae) }\end{array}$} \\
\hline
\end{tabular}

(Norkko \& Bonsdorff 1996a,b,c, Norkko et al. 2000, Österling \& Pihl 2001). We observed only 1 clam in the algal mat during our laboratory experiment. The lack of movement into algal mats by $M$. arenaria could be explained by the lower mobility of these clams compared to other clam species, as well as the age of the clams used in our experiment. We used clams $>20 \mathrm{~mm}$; clams $<20 \mathrm{~mm}$ are more agile because of the need to re-burrow if washed away (Matthiessen 1960, Hunt \& Mullineaux 2002).

\section{Reasons underlying changes in burial depth}

Hypoxic conditions cause organisms to alter their behavior and physiological condition (Diaz \& Rosenberg 1995), and infaunal animals commonly respond to such conditions by emerging at the sediment surface (Jørgensen 1980). For example, Mya arenaria, in Limfjorden (Denmark) and in laboratory experiments, responded to low oxygen saturation (that was not induced by algal mats) by extending their siphon above the sediment surface or by completely emerging and lying on the sediment, thus allowing maximum siphon extension above the hypoxic layer at the sediment-water interface (Jørgensen 1980, Rosenberg et al. 1991, Taylor \& Eggleston 2000).

In our laboratory experiment and during our field-sampling study, hypoxic conditions developed in the sediments in the presence of algae, as indicated by the blackness and sulfurous smell of the sedi- ments. However, in our laboratory experiment, the oxygen concentration at the sediment-algal interface did not reach hypoxic values (which would be between 0.0 and $2.0 \mathrm{ml} \mathrm{l}^{-1}$, Diaz \& Rosenberg 1995), and the observed trend of lower oxygen concentration at the sediment surface in the presence of algae was not significant. These observations are likely to be due to the flowing seawater and simulated tidal cycles in our experiment. Also, since our experiment lasted $7 \mathrm{~d}$, it is possible that oxygen levels under the algal mats did not have time to reach hypoxic values. Other studies documenting hypoxic levels at the sediment interface under algal mats did not have flowing water, thus likely enhancing oxygen depletion at the sediment interface (Norkko \& Bonsdorff 1996c, Norkko et al. 2000, Österling \& Pihl 2001). In addition, the volume of water collected at the sediment interface in our experiment was relatively large $(180 \mathrm{ml})$; we may have collected aquarium water, high in oxygen, along with interface water, thus contaminating our samples.

We detected significantly higher DOC values in pore water under thick algal mats than under thin or absent algal mats in our laboratory experiment. Organic 
enrichment of sediments results from the decomposition of organic matter, as well as dissolved organic carbon exuded by algae (Valiela et al. 1997). Sediment enrichment increases benthic oxygen demand by bacteria and fauna associated with algal mats and underlying sediments, creating hypoxic conditions (Valiela et al. 1997). Benthic respiration measurements from our field study were approximately 3 times higher in areas covered with algae than those in clear areas, indicating higher oxygen uptake under algal mats.

Hypoxic conditions allow sulfate-reducing bacteria, usually deep in the sediment, to survive at the surface. This results in hydrogen sulfide production at the surface, which can be lethal to infaunal species (Jørgensen 1980, Nicholls et al. 1981, Everett 1994, Diaz \& Rosenberg 1995, Norkko \& Bonsdorff 1996a,b,c). Laboratory studies have shown that high hydrogen sulfide concentrations in the sediment intensify the negative effects of hypoxia (such as decreased survival, Diaz \& Rosenberg 1995). In both our laboratory experiment and field observations, black, sulfurous-smelling sediments under algal mats indicated hydrogen sulfide production. In addition, values of total sulfides in the field were significantly higher under algal mats than in algae-free areas. Further, areas clear of algal mats at impacted sites might have been covered with algae in the past; therefore, these areas could still record higher levels of total sulfides than reference sites. Although our measurements for respiration and total sulfides were not taken at the same time as those for burial depth, black, sulfurous-smelling sediments under algae were observed throughout the period for the field study (Auffrey 2003).

Toxic exudates, released by macroalgal mats, may cause escape responses in infaunal animals (Norkko \& Bonsdorff 1996a,c, Österling \& Pihl 2001). Although green algae are thought to have the least amount of toxic exudates (Valiela et al. 1997), activated toxins resulting from predator damage have been found in them (van Alstyne et al. 2001). We were careful to remove any fauna from the algae used in the laboratory experiment. However, it is possible that damage done prior to the experiment could have caused some toxin production. Green macroalgal mats could also release nonpredator-induced toxins. For example, Ulva lactuca releases a non-predator-induced toxin which, acting in combination with oxygen depletion, may cause mortality in marine invertebrates (Johnson \& Welsh 1985).

The physical cover of algal mats may also cause vertical migration in infaunal species (Norkko \& Bonsdorff 1996a,b,c, Österling \& Pihl 2001). We did not test this hypothesis directly, but algal mats do impose a physical barrier between clams and the water column by reducing the water flow over the sediment surface (Escartin \& Aubrey 1995). In our laboratory experiment, Мya arenaria quickly re-burrowed after algae removal- indicating that algae may impose a physical stress. By mimicking algal mat cover using nylon mesh, Raffaelli et al. (1991) found that the physical presence of the cover changed the behavior of crustacean infauna. Furthermore, benthic infauna (e.g. Macoma balthica) responded more quickly to hypoxia induced by algal mats than to hypoxia alone in the laboratory and in the field (Norkko \& Bonsdorff 1996c).

In summary, hypoxic conditions, sulfides, other toxic substances, and physical cover may act in combination to cause an escape response in infaunal animals. Currently, hypoxia is thought to be the most important factor inducing vertical migration in infaunal animals (Norkko \& Bonsdorff 1996a,b,c, Norkko et al. 2000, Österling \& Pihl 2001). However, the relative importance of each of the possible factors and the interactions between them have yet to be determined.

\section{Implications of changes in burial depth}

Changes in the burial depth of soft-shelled clams, brought about by the presence of macroalgal mats, may have complex effects on clam populations and on the surrounding environment. Soft-shelled clams avoid predators and extreme temperatures, and prevent being washed away, by burrowing deep in sediments (Blundon \& Kennedy 1982b, Zwarts \& Wanink 1989, Zaklan \& Ydenberg 1997). Yet, infaunal suspension feeders, such as soft-shelled clams, obtain food and oxygen by pumping and filtering water, in quantities which are proportional to the rate of flow through the elastic siphon. For a given clam, this rate of flow is inversely proportional to the length of the siphon, because a longer siphon stretch results in a smaller siphonal radius (as per Poisseuille's equation in Vogel 1983). Thus, for a given environmental concentration of oxygen, a clam's uptake should be inversely proportional to burial depth. Decreased burial depth under algal mats increases siphonal radius, which should lead to increases in pumping rate and oxygen uptake in low-oxygen waters, such as those under the mats. However, there is a trade-off between the rate of oxygen uptake or suspension feeding and predator avoidance (Blundon \& Kennedy 1982b, Zwarts \& Wanink 1989, Zaklan \& Ydenberg 1997). Risk of predation by benthic predators, such as crabs, increases with decreasing burial depth. In the presence of green macroalgal mats, predators may have easier access to abundant prey. Further, this increase in easily available prey may lead to increases in predator abundance. Indeed, the green crab Carcinus maenas, an important predator of soft-shelled clams (Glude 1955, Ropes 1968), has been observed to increase in numbers in the presence of macroalgal mats (Nicholls et al. 
1981, Soulsby et al. 1982, L. M. Auphrey pers. obs.). However, the effect of algal mats on predator-prey interactions between crabs and clams may not be so simple. Clams under algal mats are stressed, and may not be a preferred prey for crabs. For example, blue crabs Callinectes sapidus have been observed to ignore clams lying on the substrate surface in the laboratory (Blundon \& Kennedy 1982a). Crab predation may also be hindered by the physical structure of algal mats or by hypoxia induced by these mats (Taylor \& Eggleston 2000).

Decreased burial depth of clams may also have effects on the benthic and pelagic environment. For example, suspension-feeding bivalves are important in benthic-pelagic coupling (Cloern 1982, Rosenberg \& Loo 1988, Loo \& Rosenberg 1989, Peterson et al. 1994) because they filter large amounts of water. Their filtering activity may reduce eutrophication and phytoplankton blooms (Officer et al. 1982, Newell 1988, Gili \& Coma 1998). If reduced burial depth leads to increased pumping volume, then eutrophication and phytoplankton blooms may further be reduced (that is, if clam density is not also reduced by the agent causing the decreased burial depth). Another example is related to the role of soft-shelled clams in benthic chemistry. Changes in clam burial depth may lead to changes in the denitrification, sulfate reduction and depth of ventilation in sediments (Pelegrí \& Blackburn 1995, Hansen et al. 1996).

Soft-shelled clams are an important economic resource in North America. However, in the ScotiaFundy region of Canada, estimated commercial catches are declining (537 metric tonnes in 1989 to 153 metric tonnes in 2001, data from the Department of Fisheries and Oceans, Canada). Green macroalgal mats are affecting populations, already impacted by harvesting, diseases and predation by green crabs (Robinson \& Rowell 1990, Barber et al. 2002, Auffrey 2003). Behavioral changes, such as shallower burial depth and even complete surfacing, will likely result in increased predation and further population declines.

Acknowledgements. We thank N. Johnson for her help in the field and laboratory, M. Tingley (Applied Statistics Centre, University of New Brunswick) and D. J. Arsenault for statistical advice, and D. J. Arsenault, T.B.R. Chopin and anonymous reviewers for comments on the manuscript. We also thank $\mathrm{P}$. Kepkay and J. Bugden for DOC analysis, B. Hargrave, G. Phillips and L. Doucette for respiration and sulfide data, and staff at the St. Andrews Biological Station for logistical and technical support. This study was mainly funded by a grant for Environmental Studies for Sustainable Aquaculture from the Department of Fisheries and Oceans Canada to S.M.C.R. Additional funding was provided by a Graduate Research Award from the University of New Brunswick to L.M.A. and a grant from the Natural Science and Engineering Research of Canada (a Discovery Grant) to M.A.B.

\section{LITERATURE CITED}

Auffrey LM (2003) Effects of green macroalgal mats on softshelled clams (Mya arenaria L.) in southwestern New Brunswick, Canada. MSc thesis, University of New Brunswick, Fredericton

Barber BJ, MacCallum GS, Robinson SMC, McGladdery S (2002) Occurrence and lack of transmissibility of gonadal neoplasia in softshell clams, Mya arenaria, in Maine (USA) and Atlantic Canada. Aquat Living Resour 15:319-326

Blundon JA, Kennedy VS (1982a) Mechanical and behavioral aspects of blue crab, Callinectes sapidus (Rathbun), predation on Chesapeake Bay bivalves. J Exp Mar Biol Ecol 65:47-65

Blundon JA, Kennedy VS (1982b) Refuges for infaunal bivalves from blue crab, Callinectes sapidus (Rathbun), predation in Chesapeake Bay. J Exp Mar Biol Ecol 65: 67-81

Bonsdorff E (1992) Drifting algae and zoobenthos_effects on settling and community structure. Neth J Sea Res 30: $57-62$

Bugden JBC, Hargrave BT, Strain PM, Stewart ARJ (2001) Spatial patterns of some physical and chemical variables in Passamaquoddy Bay and Letang Inlet, southwestern Bay of Fundy, September 1999. Can Tech Rep Fish Aquat Sci 2356

Cloern JE (1982) Does the benthos control phytoplankton biomass in South San Franscisco Bay? Mar Ecol Prog Ser 9: 191-202

Cloern JE (2001) Our evolving conceptual model of the coastal eutrophication problem. Mar Ecol Prog Ser 210: $223-253$

Diaz RJ, Rosenberg R (1995) Marine benthic hypoxia: a review of its ecological effects and the behavioural responses of benthic macrofauna. Oceanogr Mar Biol Annu Rev 33:245-303

Escartin J, Aubrey DG (1995) Flow structure and dispersion within algal mats. Estuar Coast Shelf Sci 40:451-472

Everett RA (1994) Macroalgae in marine soft-sediment communities: effects on benthic faunal assemblages. J Exp Mar Biol Ecol 175:253-274

Gili JM, Coma R (1998) Benthic suspension feeders: their paramount role in littoral marine food webs. Trends Ecol Evol 13:451-472

Glude JB (1955) The effects of temperature and predators on the abundance of the soft-shell clam, Mya arenaria, in New England. Trans Am Fish Soc 84:13-26

Hansen K, King GM, Kristensen E (1996) Impact of the softshell clam Mya arenaria on sulfate reduction in an intertidal sediment. Aquat Microb Ecol 10:181-194

Hargrave BT, Prouse NJ, Phillips GA, Neame PA (1983) Primary production and respiration in pelagic and benthic communities at two intertidal sites in the Upper Bay of Fundy. Can J Fish Aquat Sci 40:229-243

Hargrave BT, Doucette LI, White MJ, Phillips GA, Milligan TG (1995) Biogeochemical observations to assess benthic impacts of organic enrichment from marine aquaculture in the western isles region of the Bay of Fundy, 1994. Can Tech Rep Fish Aquat Sci 2062

Hawkins CM, Rowell TW (1987) The importance of cleansing in the calculation of condition index in the soft-shelled clam, Mya arenaria (L.). J Shellfish Res 6:85-88

Huitema BE (1980) The analysis of covariance and alternatives. John Wiley \& Sons, New York

Hull SC (1987) Macroalgal mats and species abundances: a field experiment. Estuar Coast Shelf Sci 25:519-532

Hunt HL, Mullineaux LS (2002) The role of predation and 
postlarval transport in recruitment of the soft shell clam (Mya arenaria). Limnol Oceanogr 47:151-164

Isaksson I, Pihl L (1992) Structural changes in benthic macrovegetation and associated epibenthic faunal communities. Neth J Sea Res 30:131-140

Johnson DA, Welsh BL (1985) Detrimental effects of Ulva lactuca (L.) exudates and low oxygen on estuarine crab larvae. J Exp Mar Biol Ecol 86:73-83

Jørgensen BB (1980) Seasonal oxygen depletion in the bottom waters of a Danish fjord and its effect on the benthic community. Oikos 34:68-76

Kolbe K, Kaminiski H, Michaelis H, Obert B, Rahmel J (1995) Macroalgal mass development in the Wadden Sea: first experiences with a monitoring system. Helgol Meeresunters 49:519-528

Lavery PS, McComb AJ (1991) Macroalgal-sediment nutrient interactions and their importance to macroalgal nutrition in a eutrophic estuary. Estuar Coast Shelf Sci 32:281-295

Levy EM, Cunningham CC, Conrad CDW, Moffatt JD (1977) The determination of dissolved oxygen in sea water. Bedford Institute of Oceanography Report Series BI-R-77-9, Dartmouth, NS

Loo LO, Rosenberg R (1989) Bivalve suspension-feeding dynamics and benthic-pelagic coupling in an eutrophicated marine bay. J Exp Mar Biol Ecol 130:253-276

Matthiessen, GC (1960) Intertidal zonation in populations of Mya arenaria. Limnol Oceanogr 5:381-388

Newell RIE (1988) Ecological Changes in Chesapeake Bay: are they the result of overharvesting the Eastern oyster (Crassostrea virginica)? In: Lynch MP, Krome EC (eds) Understanding the estuary: advances in Chesapeake Bay research. Chesapeake Research Consortium Publication 129 (CBP/TRS 24/88). Chesapeake Research Consortium, Gloucester Point, VA, p 536-546

Nicholls DJ, Tubbs CR, Haynes FN (1981) The effect of green algal mats on intertidal macrobenthic communities and their predators. Kiel Meeresforsch Sonderh 5:511-520

Norkko A, Bonsdorff E (1996a) Rapid zoobenthic community responses to accumulations of drifting algae. Mar Ecol Prog Ser 131:143-157

Norkko A, Bonsdorff E (1996b) Population responses of coastal zoobenthos to stress induced by drifting algal mats. Mar Ecol Prog Ser 140:141-151

Norkko A, Bonsdorff E (1996c) Altered benthic prey-availability due to episodic oxygen deficiency caused by drifting algal mats. PSZN I: Mar Ecol 17:355-372

Norkko J, Bonsdorff E, Norkko A (2000) Drifting algal mats as an alternative habitat for benthic invertebrates: species specific responses to a transient resource. J Exp Mar Biol Ecol 248:79-104

Officer CB, Sayda TJ, Mann R (1982) Benthic filter feeding: a natural eutrophication control. Mar Ecol Prog Ser 9:203-210

Österling M, Pihl L (2001) Effects of filamentous green algal mats on benthic macrofaunal functional feeding groups. J Exp Mar Biol Ecol 263:159-183

Pelegrí SP, Blackburn TH (1995) Effects of bioturbation by Nereis sp., Mya arenaria and Cerastoderma sp. on nitrification and denitrification in estuarine sediments. Ophelia 42:289-299

Peterson CH, Irlandi EA, Black R (1984) The crash in suspension-feeding bivalve populations (Katelysia spp) in Princess Royal Harbour: an unexpected consequence of eutrophication. J Exp Mar Biol Ecol 176:39-52
Potvin C, Lechowicz MJ, Tardif S (1990) The statistical analysis of ecophysiological response curves obtained from experiments involving repeated measures. Ecology 71: $1389-1400$

Raffaelli D, Limia J, Hull S, Pont S (1991) Interactions between the amphipod Corophium volutator and macroalgal mats on estuarine mudflats. J Mar Biol Assoc UK 71: 899-908

Reise K, Herre E, Sturm M (1989) Historical changes in the benthos of the Wadden Sea around the Island of Sylt in the North Sea. Helgol Meeresunters 43:417-433

Robinson SMC, Rowell TW (1990) A re-examination of the incidental fishing mortality of the traditional clam hack on the soft-shell clam, Mya arenaria Linnaeus, 1758. J Shellfish Res 9:283-289

Ropes JW (1968) The feeding habits of the green crab, Carcinus maenas (L.). US Fish Bull 67:183-203

Rosenberg R (1985) Eutrophication-the future marine coastal nuisance? Mar Pollut Bull 16:227-231

Rosenberg R, Loo LO (1988) Marine eutrophication induced oxygen deficiency: effects on soft bottom fauna, western Sweden. Ophelia 29:213-225

Rosenberg R, Hellman B, Johansson B (1991) Hypoxic tolerance of marine benthic fauna. Mar Ecol Prog Ser 79: $127-131$

Soulsby PG, Lowthion D, Houston M (1982) Effects of macroalgal mats on the ecology of intertidal mudflats. Mar Pollut Bull 13:162-166

Strain PM, Yeats PA (1999) The relationship between chemical measures and potential predictors of the eutrophication status of inlets. Mar Pollut Bull 38:1163-1170

Strasser M (1999) Mya arenaria-an ancient invader of the North Sea coast. Helgol Meeresunters 52:309-324

Tabachnick BG, Fidell LS (1983) Using multivariate statistics. Harper \& Row, New York

Taylor DL, Eggleston DB (2000) Effects of hypoxia on an estuarine predator-prey interaction: foraging behavior and mutual interference in the blue crab Callinectes sapidus and the infaunal clam prey Mya arenaria. Mar Ecol Prog Ser 196:221-237

Thiel M, Stearns LM, Watling L (1998) Effects of green algal mats on bivalves in a New England mud flat. Helgol Meeresunters 52:15-28

Valiela I, McClelland J, Hauxwell J, Behr PJ, Hersh D, Foreman K (1997) Macroalgal blooms in shallow estuaries: controls and ecophysiological and ecosystem consequences. Limnol Oceanogr 42:1105-1118

van Alstyne KL, Wolfe GV, Freidenburg TL, Neill A, Hicken C (2001) Activated defense systems in marine macroalgae: evidence for an ecological role for DMSP cleavage. Mar Ecol Prog Ser 213:53-65

Vogel BS (1983) Life in moving fluids: the physical biology of flow. Princeton University Press, Princeton, NJ

Winer BJ (1971) Statistical principles in experimental design, 2nd edn. McGraw-Hill, New York

Zaklan SD, Ydenberg R (1997) The body size-burial depth relationship in the infaunal clam Mya arenaria. J Exp Mar Biol Ecol 215:1-17

Zar JH (1999) Biostatistical analysis, 4th edn. Prentice Hall, Upper Saddle River, NJ

Zwarts L, Wanink J (1989) Siphon size and burying depth in deposit- and suspension-feeding benthic bivalves. Mar Biol 100:227-240

Submitted: July 11, 2002; Accepted: April 8, 2004

Proofs received from author(s): August 18, 2004 